H. Khudov, I. Khizhnyak

Ivan Kozhedub Kharkiv National Air Force University, Kharkiv, Ukraine

\title{
COMPARATIVE ASSESSMENT OF THE OPTICAL-ELECTRONIC IMAGES SEGMENTATION QUALITY BY THE ANT COLONY OPTIMIZATION AND THE ARTIFICIAL BEE COLONY
}

\begin{abstract}
The article discusses the methods of swarm intelligence, namely, an improved method based on the ant colony optimization and the method of an artificial bee colony. The goal of the work is to carry out a comparative assessment of the optical-electronic images segmentation quality by the ant colony optimization and the artificial bee colony. Segmentation of tonal optical-electronic images was carried out using the proposed methods of swarm intelligence. The results of the segmentation of optical-electronic images obtained from the spacecraft are presented. A visual assessment of the quality of segmentation results was carried out using improved methods. The classical errors of the first and second kind of segmentation of optoelectronic images are calculated for the proposed methods of swarm intelligence and for known segmentation methods. The features of using each of the proposed methods of swarm intelligence are determined. The tasks for which it is better to use each of the proposed methods of swarm intelligence are determined.
\end{abstract}

Keywords: segmentation, optical-electronic image, swarm intelligence, the ant colony optimisation, the artificial bee colony, assessment of quality, errors of the first and second kind.

\section{Introduction}

Today, data of the remote sensing of the Earth have become available to a wide range of users. They are actively used for many purposes in the fields of life. Scientific and technical achievements in the field of creation and development of space remote sensing systems, technologies for obtaining, processing and thematic interpretation of data have many times expanded the list of tasks that are solved with their help [1].

Currently, most data of the remote sensing of the Earth is obtained from space. Large one-time coverage of the captured territory of the Earth's surface, high temporal, spatial and spectral resolution of satellite images allow to receive large amounts of data on the territory of interest in an on-line mode [2]. Data of the remote sensing of the Earth are raster optical-electronic images presented in digital form. Therefore, their processing and interpretation is closely related to digital image processing.

Today, a fairly large number of different methods of digital processing of space images are known [2-5]. The well-known methods of digital image processing were analyzed: Otsu, Canny, Random forest, k-means [6-8]. Their advantages and disadvantages in the processing of optical-electronic images have been determined. The processing of the considered methods of optoelectronic images was carried out. An assessment of the quality of processing results by known methods has been carried out.

Specialized software for digital image processing is considered (ScanViewer, ERDAS IMAGINE, ER Mapper, ENVI, GRASS, IMAGE Transformer, INTERGRAPH, TNTmips, Arc View, MODIS Proces- sor, ScanMagic, IRS Processor) [9-13]. These software products are intended for processing data from remote sensing of the Earth.

Specialized software for digital image processing, which are designed to process data from remote sensing of the Earth, are considered. The analysis showed that the software uses known image processing techniques.

The analysis of the methods of swarm intelligence, which work well in the processing of medical images, has been carried out [14]. Their features are considered. In works [15-16] it is proposed to use the methods of swarm intelligence for the segmentation of opticalelectronic images, namely the ant colony optimization and the artificial bee colony.

The goal of this work is carrying out comparative assessment of the optical-electronic images segmentation quality by the ant colony optimization and the artificial bee colony. Determination of tasks for which it is better to use one of the proposed methods of swarm intelligence.

\section{Statement of basic materials}

Formulation of the problem in general. Let's denote the original optical-electronic image - $f(x, y)$, the result of segmentation of the original optical-electronic image - $f_{s}(x, y)$.

Then the process of segmentation can be represented as an expression (1):

$$
f(x, y) \rightarrow f_{s}(x, y) .
$$

Let us point out some assumptions and limitations that must be taken into account when segmentation of tone optical-electronic images using the proposed methods, namely: 
- the original image is a tonal image, in which the number of brightness gradations is equal to 256 ;

- the original image is the image after preprocessing;

- the original image is undistorted;

- the original image must contain objects, the total area of which should not exceed the total area of the background;

- the objects on the image in comparison with the background should be compact and low-contrast.

The generalized description of the methods of the swarm intelligence can be represented in the form (2) [17]:

$$
S I=\{S, M, A, P, \text { In }, \text { Out }\},
$$

where $S I$ - swarm intelligence (method based on the ant colony optimization and the method of an artificial bee colony);

$S$ - the set of agents (ants or bees);

$M$ - an object for the exchange of information between agents (ants or bees);

$A$ - the rules of operation of methods of swarm intelligence;

$P$ - the set of parameters that are used in rules $A$;

In - input of the method of swarm intelligence;

Out - output of the method of swarm intelligence.

Let us give a generalized scheme of communication between agents of the considered methods of swarm intelligence with the external environment (Fig. 1),

where $f(x)$ - the original optical-electronic image;

$G(\mathbf{X})$ - limitations of the method of swarm intelligence;

$\varphi\left(\mathbf{X}_{i j}\right)$ - the fitness function;

$I n_{f f}-$ input that receive the fitness function $\varphi\left(\mathbf{X}_{i j}\right) ;$

$I n_{\text {lim }}$ - input that receive limitations $G(\mathbf{X})$;

$I n_{f b}$ - input for feedback;

$U_{c i}$ - the controlling influences, for example, start, stop, method parameters, etc.;

$\mathbf{X}_{\text {final }}^{\text {best }}$ - the best-found solution to the problem by the method of swarm intelligence;

$\varphi\left(\mathbf{X}_{\text {final }}^{\text {best }}\right)$ - the best-found value the fitness function $\varphi\left(\mathbf{X}_{i j}\right)$;

Out $_{b f s}$ - output for the best-found solution $\mathbf{X}_{\text {final }}^{\text {best }}$;

Out $_{b f f}$ - output for the best-found value the fitness function $\varphi\left(\mathbf{X}_{i j}\right)$;

Out $f b$ - output for feedback.

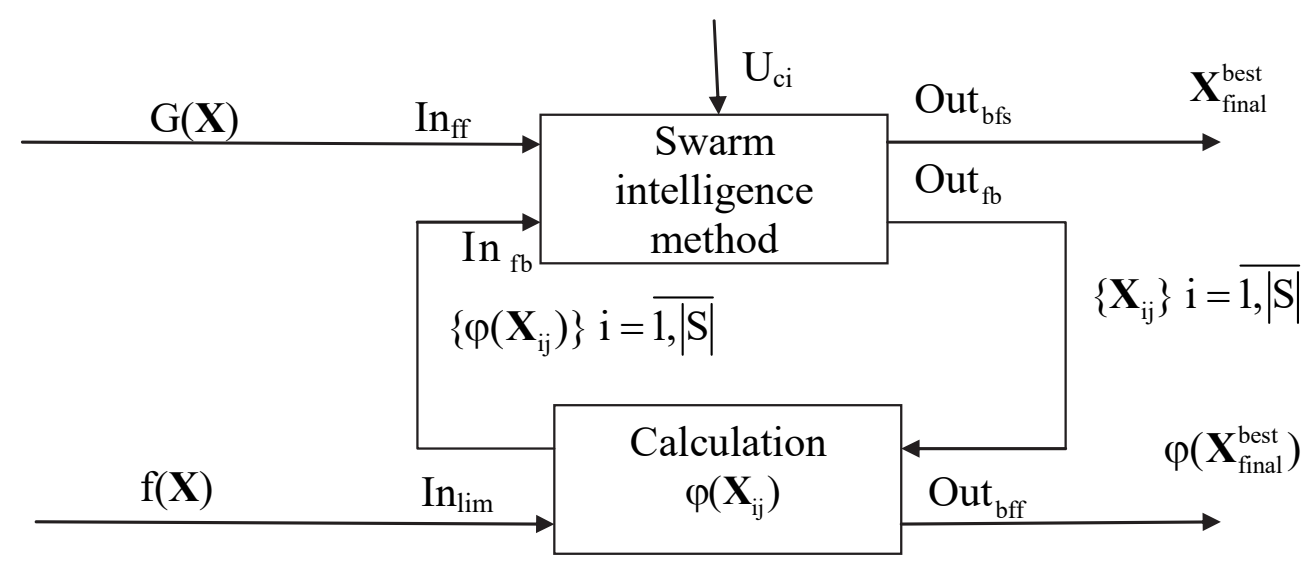

Fig. 1. A generalized scheme of communication between agents with the external environment A source: adapted from [17].

Consider the sequence of actions improved method based on the ant colony optimization and the method of an artificial bee colony for the segmentation of opticalelectronic images.

The method of segmentation of the opticalelectronic images by the ant colony optimization

The main steps of the method by ant colony optimization are as follows [18]:

1. Generation of the initial positions of the ants on the original image.
This generation is performed on the first iteration of the method, i.e. $(j=1)$ (expression (3)):

$$
\mathbf{X}_{i 1}=\operatorname{rand}(f(\mathbf{X})),
$$

where $\mathbf{X}_{i 1}=\left(x_{i 1}, y_{i 1}\right)$ - the vector of the positions of ants on the first iteration of the method, $i=1,2, \ldots, S$;

$S$ - total number of ants.

In this case, the total number of ants $S$ is equal to the total number of pixels on the original image. 
2. Calculation of the fitness function on the $j$-th iteration.

The form of the objective function on the $j$-th iteration is described by expression (4):

$$
\varphi_{j}(\mathbf{X})=\sum_{m=1}^{S} \sum_{i=1}^{N}\left(P_{i}^{m}(j) \cdot D_{i}^{m}(j)\right),
$$

where $m$ - the current number of the ant;

$N$ - size of the original image;

$P_{i}^{m}(j)$ - the probability of the transition of the $m$-th ant to $i$-th turning point of the route during the $j$-th iteration;

$P_{i}^{m}(j)$ is calculated according to the expression (5):

$$
P_{i}^{m}(j)=\frac{\left(F_{i}^{m}(j)\right)^{\alpha} \cdot\left(L_{i}^{m}(j)\right)^{\beta}}{\sum_{r=1}^{R}\left(F_{r}^{\alpha}(j) \cdot L_{r}^{\beta}(j)\right)},
$$

$D_{i}^{m}(j)$ - the length of the route section, taking into account the difference in the brightness of neighboring pixels for $m$-th ant at the $i$-th image point on the $j$-th iteration;

$D_{i}^{m}(j)$ is calculated according to the expression (6):

$$
D_{i}^{m}(j)=\left|\Delta x_{i}^{m}(j)\right|+\left|\Delta y_{i}^{m}(j)\right|+k\left|\Delta f_{i}^{m}(j)\right|,
$$

where $\alpha-$ a parameter that sets the weight of the pheromone of ants;

$\beta$ - a parameter that sets the "greed" of the method;

$R$ - number of possible turning points on the route;

$L_{i}^{m}(j)$ - the attractiveness of the route section for the $m$-th ant at the $i$-th image's point on the $j$-th iteration;

$F_{i}^{m}(j)$ - the concentration of the $m$-th ant's pheromone at the $i$-th image's point on the $j$-th iteration;

$$
\left|\Delta x_{i}^{m}(j)\right| \text { - the elementary movements of the }
$$

$m$-th ant at the $i$-th image's point on the $j$-th iteration along the $x$ axis;

$\left|\Delta y_{i}^{m}(j)\right|$ - the elementary movements of the $m$-th ant at the $i$-th image's point on the $j$-th iteration along the $y$ axis;

$k$ - the coefficient that takes into account the difference in scales along the $x$ and $y$ axes, brightness of image pixels, different units of measurement of elementary displacements and brightness. $k=1$ - provided that the brightness takes a value from the range $[0 \ldots 255]$;

$\left|\Delta f_{i}^{m}(j)\right|$ - the difference in brightness of neighboring pixels for the $m$-th ant at the $i$-th image's point on the $j$-th iteration. This difference is determined according to the expression (7):

$$
\left|\Delta f_{i}^{m}(j)\right|=\left|f\left(x_{i}^{m}(j), y_{i}^{m}(j)\right)-f\left(x_{i-1}^{m}(j), y_{i-1}^{m}(j)\right)\right| \text {. }
$$

3. Migration of ants.

At each iteration $m$ ants search for a solution and update pheromones along the route.

Every $m$-th agent:

- starts his way from the exit point of the route;

- sequentially goes through all the selected points that are selected using this method. These are the socalled turning points of the route;

- ends the path at one of the end points of the route.

The movement of ants occurs according to the criterion of the minimum fitness function. Fitness function (4), taking into account the four-connectedness of the movement of ants (8):

$$
\left|\Delta x_{i}^{m}(j)\right|+\left|\Delta y_{i}^{m}(j)\right|=1,
$$

takes the form (9):

$$
\varphi_{j}(\mathbf{X})=
$$

$=\sum_{m=1}^{S} \sum_{i=1}^{N}\left(P_{i}^{m}(j) \cdot\left(1+k\left|\begin{array}{l}f\left(x_{i}^{m}(j), y_{i}^{m}(j)\right)- \\ -f\left(x_{i-1}^{m}(j), y_{i-1}^{m}(j)\right)\end{array}\right|\right)\right) \rightarrow \min$.

The attractiveness of the section of route $L_{i}^{m}(j)$ for $m$-th ant at the $i$-th image's point on the $j$-th iteration inversely depends on the length of the section of the route. For example, expressions (10)-(12):

$$
\begin{gathered}
L_{i}^{m}(j)=\frac{1}{D_{i}^{m}(j)}, \\
L_{i}^{m}(j)=\frac{1}{1+\frac{D_{i}^{m}(j)}{D_{0}}}, \\
L_{i}^{m}(j)=\frac{1}{1+e^{\frac{D_{i}^{m}(j)}{D_{0}}},}
\end{gathered}
$$

where $D_{0}-$ the parameter that takes into account the scale of the image.

At the beginning of the method, the amount of pheromone on the route sections is taken equal to some small number $F_{0}$ and is the same. After each iteration of the iterative process, the concentration of pheromones is updated in the areas selected by the ants. The update occurs according to the rule (13): 


$$
F_{i}^{m}(j+1)=(1-\rho) F_{i}^{m}(j)+\sum_{m=1}^{M} \Delta F_{i}^{m},
$$

where $\rho$ - the rate of evaporation of pheromone;

$\Delta F_{i}^{m}$ - the concentration of pheromone on $i$-th section of the route, which is created by passing $m$-th agent.

As a result of carrying out a certain number of iterations, routes are determined that are the most attractive according to the selected criterion. On unattractive routes, the pheromone gradually "evaporates". Thus unattractive routes disappear.

For $\alpha=0$, the ants move to the nearest turning point of the route at each step. As a result, this method of segmentation of the images by the ant colony optimization turns into a "greedy" method of classical optimization theory.

For $\beta=0$, only the effect of pheromones is taken into account. And this will quickly lead to a suboptimal solution.

4. Checking the fulfillment of the conditions for stopping the method.

Conditions for stopping the method can be

- reaching the maximum allowable number of iterations of iterative process;

- finding the required solution;

- the absence of a significant improvement in the value of the fitness function over a certain number of iterations.

If one of the conditions is met, then the resulting segmented image $f_{s}(\mathbf{X})$ is displayed. Otherwise, the transition occurs calculation of the fitness function $\varphi_{j}(\mathbf{X})$.

The parameters $P(1)$ are determined as $P\left(\alpha, \beta, \rho, F_{0}\right)$.

Fig. 2 shows the algorithm of the method of segmentation of the optical-electronic images by the ant colony optimization.

The original image was processed by the method of segmentation of the optical-electronic images by the ant colony optimization. An optical-electronic image obtained from a spacecraft WorldView-1 was taken as the original image [19]. This optical-electronic image is presented in grayscale tones from 0 to 255 . Image size is $640 \times 640$ pixels.

This original image meets all the limitations and assumptions that must be taken into account when segmentation of tonal optical-electronic images by the proposed methods.

Fig. 3 shows the original optical-electronic image.

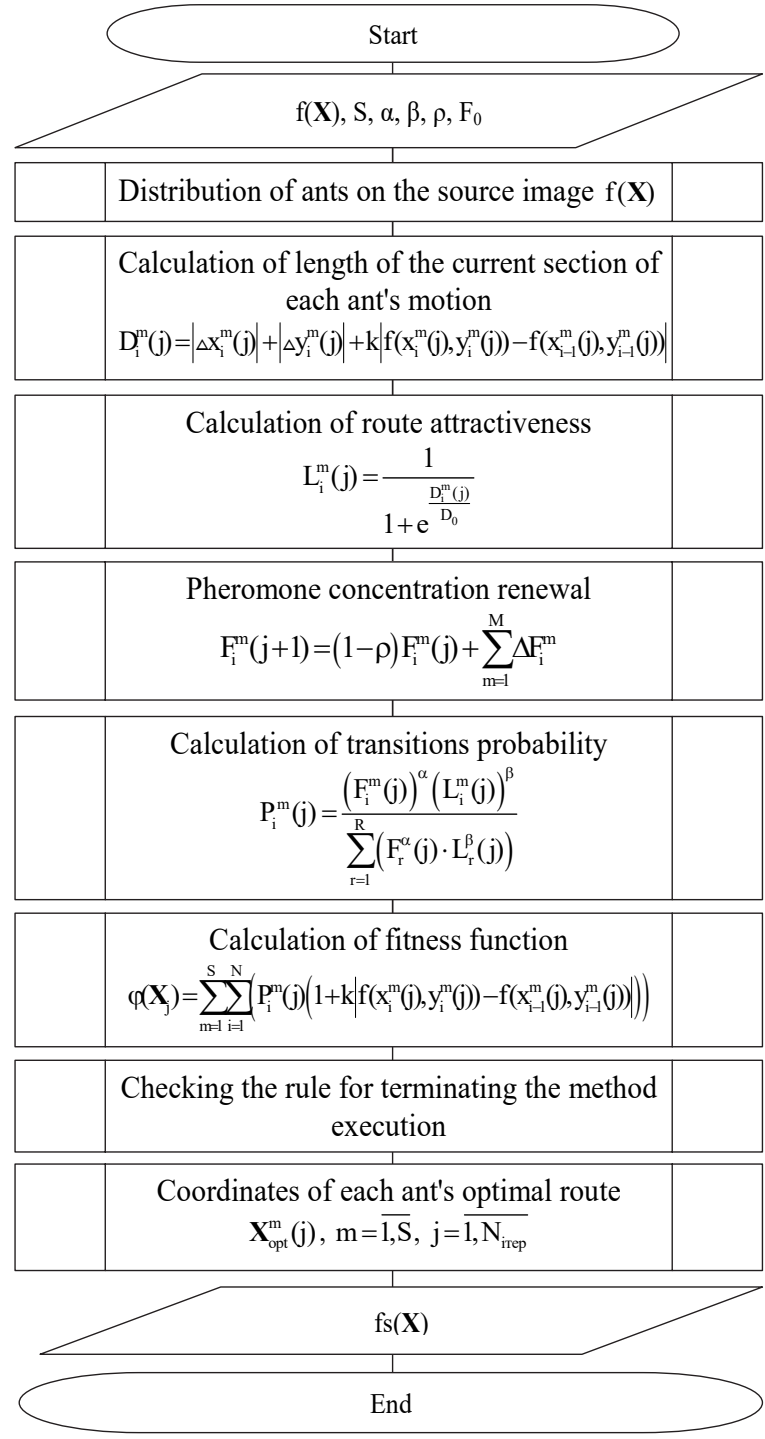

Fig. 2. The algorithm of the method of segmentation of the optical-electronic images by the ant colony optimization A source: received by authors.

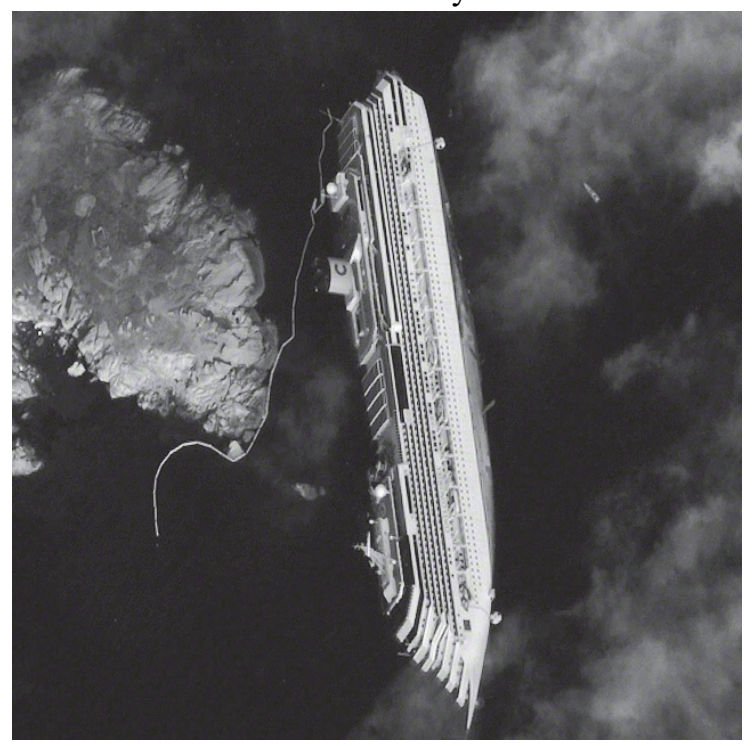

Fig. 3. The original tonal image A source: adapted from [19]. 
Fig. 4 shows the result of the method of segmentation of the optical-electronic image (Fig. 3) by the ant colony optimization.

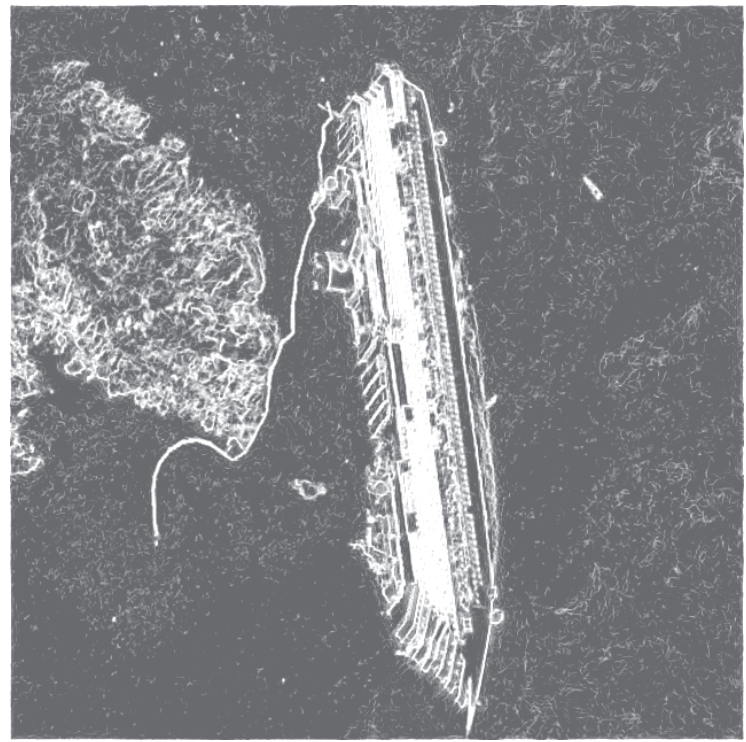

Fig. 4. The result of segmentation of the original image (Fig. 3) by the ant colony optimization A source: received by authors.

Visual assessment of the quality of the resulting image makes it easy to identify objects on the segmented image. This is a damaged sea liner. At the same time, it is seen that this method selected contours of objects on the image.

The method of segmentation of the opticalelectronic images by the artificial bee colony

The main steps of the method by the artificial bee colony are as follows [20]:

1. Generation of the initial positions of the bees on the original image. This generation is performed for $n^{s}$ scout bees only on the first iteration of the method, i.e. $(j=1)$ (expression (14)):

$$
\mathbf{X}_{i 1}=\operatorname{rand}(f(\mathbf{X})),
$$

where $\mathbf{X}=(x, y)$ - the vector of the positions of the bees;

$\mathbf{X}_{i 1}=\left(x_{i 1}, y_{i 1}\right)-$ the vector of the positions of $n^{s}$ scout bees on the first iteration of the method, i.e. $(j=1)$;

$\operatorname{rand}(f(\mathbf{X}))$ - the random number generation operator;

$$
i=1, \ldots, n^{s} \text {. }
$$

2. Calculation of the fitness function $\varphi\left(\mathbf{X}_{i j}\right)$ for each $i$-th bee $(i=1,2, \ldots,|S|)$ on the $j$-th iteration.

3. Determination of the perspective positions $N_{i j}^{p}$ and the best positions of bees $N_{i j}^{b}$, taking into account the value of $\varphi\left(\mathbf{X}_{i j}\right)$ the fitness function of each $i$-th bee.

\section{Migration of bees.}

After determining the perspective and best positions of the bees, the working bees are sent to the environment of these positions. $c^{b}$ of working bees are sent surrounded by each best position. $c^{p}$ of working bees are sent surrounded by each perspective position.

The positions of all working bees are determined according to expression (15) and (16):

$$
\mathbf{X}_{\left((i-1) c^{b}+k\right) j}=N_{i(j-1)}^{b}+\text { Rnd } \cdot \mathrm{rad},
$$

where $\mathbf{X}_{\left((i-1) c^{b}+k\right) j}$ - the vector of the positions of the best bees on the $j$-th iteration;

$N_{i j}^{b}$ - the best position of $i$-th bee on the $j$-th iteration;

$$
\begin{aligned}
& i=1, \ldots, n^{b} \\
& k=1, \ldots, c^{b} ; \\
& n^{b}-\text { the number of the best positions on the } j \text {-th }
\end{aligned}
$$
iteration;

$c^{b}$ - the number of bees that migrate (change position) to the best positions;

Rnd - the random number;

rad - the coefficient that determines the dispersion of bees when they are sent to the best and the perspective positions.

$$
\mathbf{X}_{\left(n^{b} c^{b}+(i-1) c^{b}+k\right) j}=N_{i(j-1)}^{p}+R n d \cdot \mathrm{rad},
$$

where $N_{i j}^{p}$ - the perspective position of $i$-th bee on the $j$-th iteration;

$$
\begin{aligned}
& i=1, \ldots, n^{p} ; \\
& k=1, \ldots, c^{p} ; \\
& n^{p}-\text { the number of the perspective positions on }
\end{aligned}
$$
the $j$-th iteration;

$c^{p}$ - the number of bees that migrate (change position) to the perspective positions.

In this case, the scout bees are sent to positions whose coordinates are random values. These positions are distributed evenly over the entire original image, that is, over the entire allowable range of values (expression (17)):

$$
\mathbf{X}_{\left(n^{b} c^{b}+n^{p} c^{p}+i\right) j}=\operatorname{rand}(f(\mathbf{X})),
$$

where $i=1, \ldots, n^{s}$;

$n^{s}-$ the number of the scout bees on the $j$-th iteration.

5. The coefficients and parameters of the method from expressions (14)-(15) are included to the vector of 
input parameters of the coefficients of the method (form (18)).

$$
P=\left\{n^{s}, n^{b}, n^{p}, c^{b}, c^{p}, \operatorname{rad}, r x, r y\right\},
$$

where $r x$ - the size of the circle along the $\mathrm{x}$-axis of the best and perspective positions;

$r y$ - the size of the circle along the y-axis of the best and perspective positions.

6 . The output of the method of segmentation of the optical-electronic images by the artificial bee colony is the following:

- determination of the coordinates of the optimal position of bees (at which the value of the fitness function $\varphi\left(\mathbf{X}_{i j}\right)$ will be maximum or minimum $\left.\varphi\left(\mathbf{X}_{\text {final }}^{\text {best }}\right)\right)$;

- determination of the optimal value of the segmentation threshold ( $t h$ ).

Fig. 5 shows the algorithm of the method of segmentation of the optical-electronic images by the artificial bee colony.

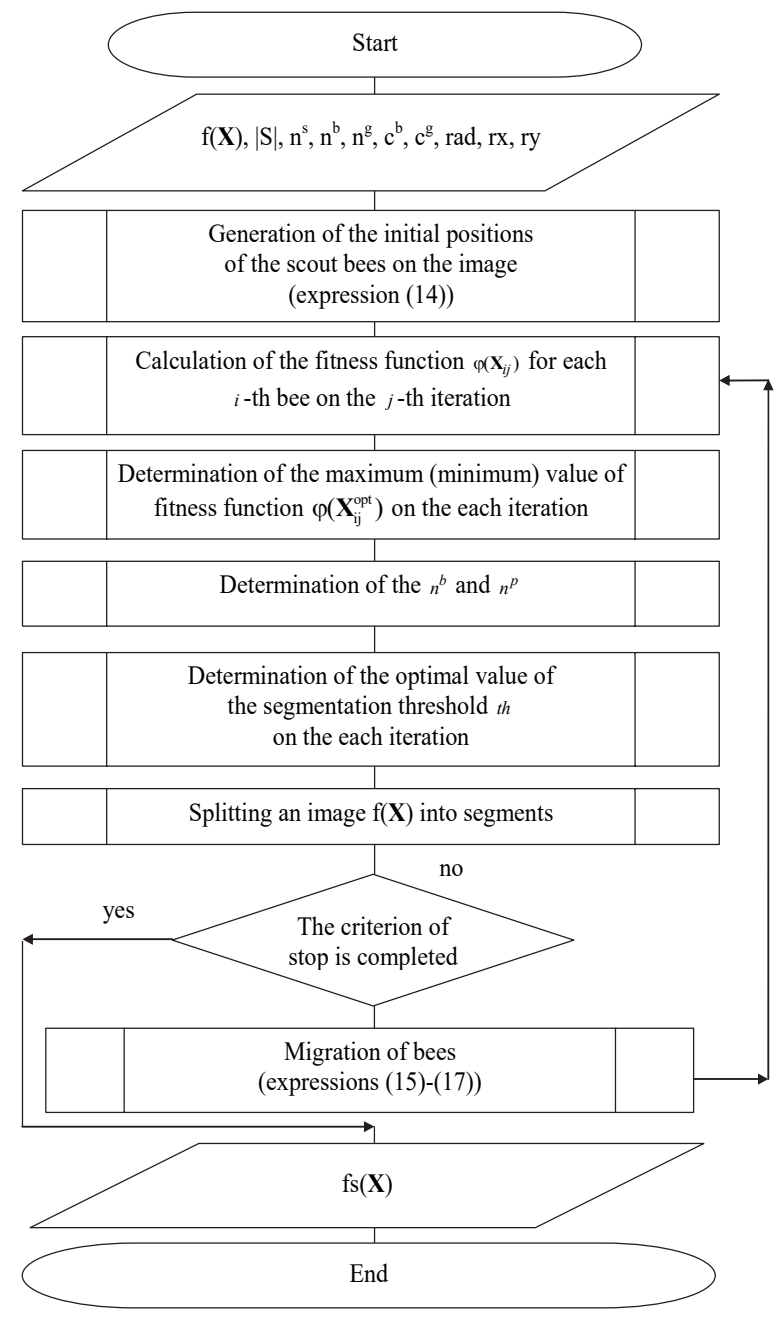

Fig. 5. The algorithm of the method of segmentation of the optical-electronic images by the artificial bee colony A source: received by authors.
The criterion of stop can be:

- reaching the maximum allowable number of iterations,

- finding the required solution,

- the absence of a significant improvement in the value of the fitness function over a certain number of iterations.

The original image was processed by the method of segmentation of the optical-electronic images by the artificial bee colony. An optical-electronic image obtained from a spacecraft Ikonos was taken as the original image [21]. This optical-electronic image is presented in grayscale tones from 0 to 255 . Image size is $868 \times 847$ pixels.

This original image meets all the limitations and assumptions that must be taken into account when segmentation of tonal optical-electronic images by the proposed methods.

Fig. 6 shows the original optical-electronic image.

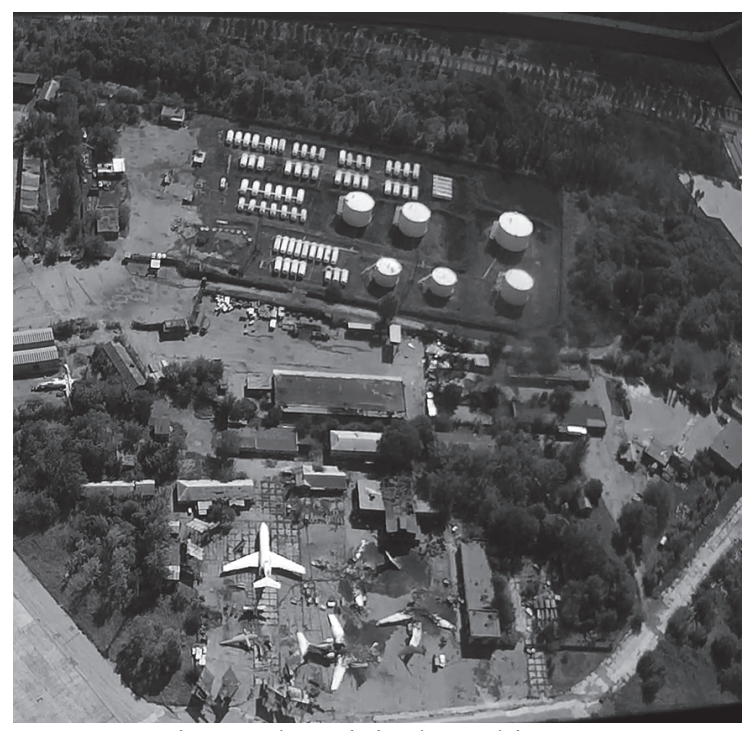

Fig. 6. The original tonal image A source: adapted from [21].

Fig. 7 shows the result of the method of segmentation of the optical-electronic image (Fig. 6) by the artificial bee colony.

Visual assessment of the quality of the resulting image makes it easy to identify objects on the segmented image. It is a whole plane, a damaged plane, airfield buildings, airfield fuel tanks. At the same time, it is clearly visible that this method selects areas on the image.

Fig. 8 shows the result of the method of segmentation of the original optical-electronic image (Fig. 6) by the ant colony optimization.

Since the method of segmentation of the opticalelectronic images by the ant colony optimization selects 


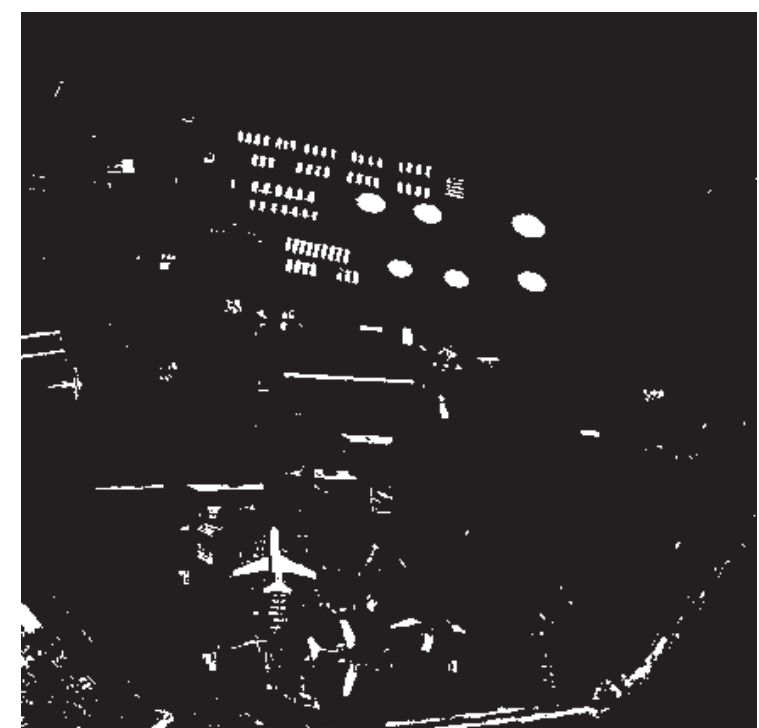

Fig. 7. The result of segmentation of the original image by the artificial bee colony

A source: received by authors.

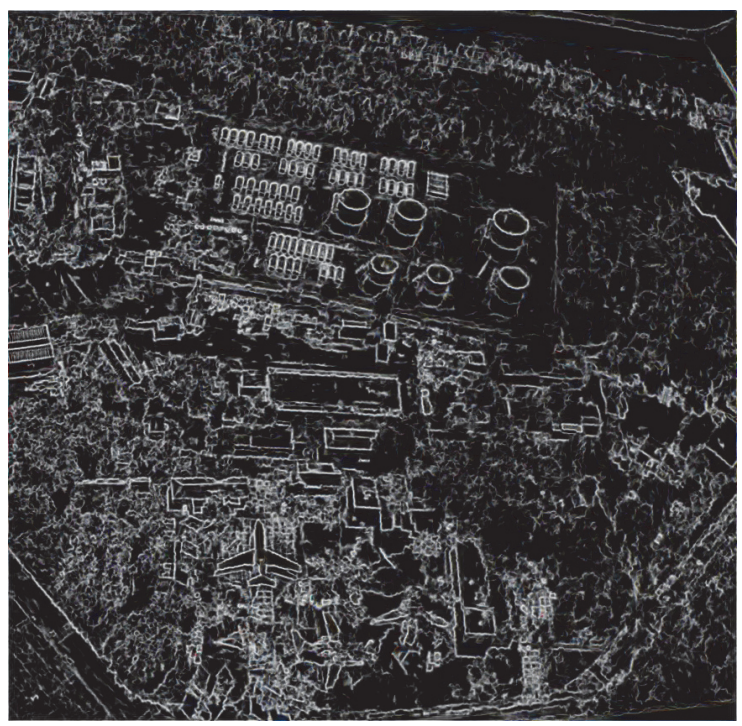

Fig. 8. The result of segmentation of the original image (Fig. 6) by the ant colony optimization

A source: received by authors. the contours of objects, then after segmentation by this method on Fig. 8 a lot of "junk" objects. The following conclusion can be drawn. The method of segmentation of the optical-electronic images by the ant colony optimization is not suitable for images with a large number of small objects.

To quantify the quality of segmentation of the optical-electronic images, the method of segmentation by the artificial bee colony and by the ant colony optimization calculated errors of the first and second kind. The image segmentation error of the first kind and the second kind is determined by the criterion of maximum likelihood. These errors are calculated according to expressions (19) and (20) [15-16]:

$$
\begin{gathered}
\alpha=\frac{S_{1}\left(f_{s}(\mathbf{X})\right)}{S_{2}(f(\mathbf{X}))}, \\
\beta=1-\frac{S_{3}\left(f_{s}(\mathbf{X})\right)}{S_{4}(f(\mathbf{X}))},
\end{gathered}
$$

where $\alpha-$ the segmentation error of the first kind;

$\beta$ - the segmentation error of the second kind;

$S_{1}\left(f_{S}(\mathbf{X})\right)$ - the area of the background areas on the resulting image $f_{S}(\mathbf{X})$, which was erroneously attributed to the objects on the image $f_{S}(\mathbf{X})$;

$S_{2}(f(\mathbf{X}))$ - the area of the background areas on the original image $f(\mathbf{X})$;

$S_{3}(f s(\mathbf{X}))$ - the area of correctly segmented objects of interest on the resulting image $f_{S}(\mathbf{X})$;

$S_{4}(f(\mathbf{X}))--$ the area of the objects of interest on the original image $f(\mathbf{X})$.

Also the values of errors of the first and second kind were calculated according to expressions (19) and (20) for the known methods of segmentation of the image. Namely for the method Otsu, Canny, k-means, Random forest.

The results of evaluating the errors of the first and second kind of segmentation of the original opticalelectronic image (Fig. 6) by the proposed and known methods are shown in Tabl. 1.

Table 1

Evaluating the errors of the first and second kind of segmentation of the original optical-electronic image (Fig. 6)

by the proposed and known methods

\begin{tabular}{|c|c|c|c|c|c|c|c|c|}
\hline $\begin{array}{c}\text { Method of } \\
\text { segmentation }\end{array}$ & Otsu & Canny & $\begin{array}{c}k \text {-means } \\
(k=2)\end{array}$ & $\begin{array}{c}k \text {-means } \\
(k=3)\end{array}$ & $\begin{array}{c}k \text {-means } \\
(k=4)\end{array}$ & $\begin{array}{c}\text { Random } \\
\text { forest }\end{array}$ & $\begin{array}{c}\text { The ant } \\
\text { colony } \\
\text { optimization }\end{array}$ & $\begin{array}{c}\text { The } \\
\text { artificial } \\
\text { bee colony }\end{array}$ \\
\hline$\alpha, \%$ & 18,30 & 10,50 & 18,50 & 17,30 & 15,50 & 15,90 & 4,15 & 3,70 \\
\hline$\beta, \%$ & 25,70 & 14,30 & 25,80 & 23,70 & 20,30 & 17,76 & 6,84 & 6,35 \\
\hline
\end{tabular}

A source: adapted from [15].

Analysis of the calculated errors of the first and second kind (Tabl. 1) shows an improvement in the quality of the tonal optical-electronic image segmenta- tion using one of the methods of swarm intelligence: the method of segmentation of the optical-electronic image by the ant colony optimization or the method of seg- 
mentation of the optical-electronic image by the artificial bee colony.

\section{Conclusions}

Thus, an improved method based on ant colony optimization and an artificial bee colony method are discussed. Segmentation of tonal optical-electronic images was carried out using the proposed methods of swarm intelligence. The results of the segmentation of optical-electronic images obtained from the spacecraft are presented.

It is established that to solve the problem of selection of areas on the optical-electronic image it is neces- sary to use the method of segmentation of the original optical-electronic image by the artificial bee colony. A visual assessment of the quality of segmentation results was carried out using improved methods. To select the contours on the optical-electronic image, it is necessary to use the method of segmentation of the original optical-electronic image by the ant colony optimization.

The classical errors of the first and second kind of segmentation of optoelectronic images are calculated for the proposed methods of swarm intelligence and for known segmentation methods. The features of using each of the proposed methods of swarm intelligence are determined.

\section{References}

1. Chemin, Y. (2012), Remote Sensing of Planet Earth, Rijeka, 250 p. https://doi.org/10.5772/2291.

2. Richards, J. (2013), Remote Sensing Digital Image Analysis. An Introduction, Springer. https://doi.org/10.1007/978-3642-30062-2.

3. Bhadoria, P., Agrawal, S. and Pandey, R. (2020), Image Segmentation Techniques for Remote Sensing Satellite Images, IOP Conference Series: Materials Science and Engineering, pp. 1-17. https://doi.org/10.1088/1757-899X/993/1/012050.

4. Kaur, H. (2015), Review of remote sensing image segmentation techniques, International Journal of Advanced Research in Computer Engineering \& Technology, Vol. 4, Issue 14, pp. 1667-1674.

5. Varghese, N. and Babu, P. (2016), A Survey on remote sensing image segmentation, International Journal of Scientific Engineering and Applied Science, Vol. 2, Issue 1, pp. 488-491.

6. Srinivas, CH. V. V. S., Prasad, M. V. R. V. and Sirisha, M. (2019), Remote Sensing Image Segmentation using OTSU Algorithm, International Journal of Computer Application, Vol. 178, No. 12, pp. 46-50.

7. Dhanachandra, N., Manglem, K. and Jina Chanu, Y. (2015), Image Segmentation Using K -means Clustering Algorithm and Subtractive Clustering Algorithm, Procedia Computer Science, Vol. 54. pp. $764-771$. https://doi.org/10.1016/j.procs.2015.06.090.

8. Gonzalez, R. C. and Woods, R. E. (2017), Digital Image Processing, Prentice Hall, 1192 p.

9. OpenCV library, available at: https://opencv.org.

10. The official site ESTI MAP (2021), "Peredovye tekhnologhyy v obrabotke DDZ" [Advanced technologies in the processing of remote sensing data], available at: www.mapinfo.ru/product/erdas.

11. ScanEx Image Processor, available at: https://www.scanex.ru/software/scanmagic/.

12. The official site SOFTPROM (2021), "Erdas Imagine - moshhnyj paket dlja obrabotky dannykh" [Erdas Imagine powerful data processing package], available at: https://softprom.com/ru/vendor/hexagon/product/erdas-imagine-.

13. The official site SCANEX (2021), "Scanex - lyder v sfere sputnykovogho monytoryngha" [Scanex - leader in satellite monitoring], available at: http://scanex.ru.

14. Sharma, N. and Aggarwal, Lalit M. (2010), Automated medical image segmentation techniques, Journal of Medical Physics, Vol. 35, No.1.pp. 3-14. https://doi.org/10.4103/0971-6203.58777.

15. Ruban, I., Khudov, H., Makoveichuk, O., Khizhnyak, I., Khudov, V., Podlipaiev, V., Shumeiko, V., Atrasevych, O., Nikitin, A. and Khudov, R. (2019), Segmentation of opticalelectronic images from on-board systems of remote sensing of the Earth by the artificial bee colony method, Eastern-European Journal of Enterprise Technologies, Vol. 98, No. 2/9, pp. 37-45. https://doi.org/10.15587/1729-4061.2019.161860.

16. Ruban, I., Khudov, H., Makoveichuk, O., Chomik, M., Khudov, V., Khizhnyak, I., Podlipaiev, V., Sheviakov, Y., Baranik, O. and Irkha, A. (2019), Construction of methods for determining the contours of objects on tonal aerospace images based on the ant algorithms, Eastern-European Journal of Enterprise Technologies, Vol. 101, No. 5/9, pp. 25-34. https://doi.org/10.15587/1729-4061.2019.177817.

17. Ruban, I., Khudov, H., Khudov, V., Khizhnyak, I. and Makoveichuk, O. (2017), Segmentation of the images obtained from onboard optoelectronic surveillance systems by the evolutionary method, Eastern-European Journal of Enterprise Technologies, Vol. 5, Issue 9(89), pp. 49-57. https://doi.org/10.15587/1729-4061.2017.109904.

18. Dorigo, M. and Stætzle, T. (2018), Ant Colony Optimization: Overview and Recent Advances, International Series in Operations Research \& Management Science, pp. 311-351. https://doi.org/10.1007/978-3-319-91086-4_10.

19. The official site of SATELLITE IMAGING CORPORATION, WorldView-1 Satellite Sensor, available at: www.satimagingcorp.com/satellite-sensors/worldview-1.

20. Karaboga, D., Gorkemli, B., Ozturk, C. and Karaboga, N. (2014), A comprehensive survey: artificial bee colony (ABC) algorithm and applications, Artificial Intelligence Review, Vol. 42, Issue 1, pp. 21-57. https://doi.org/10.1007/s10462-012-9328-0.

21. Ruban, I., Khudov, V., Makoveichuk, O., Khudov, H. and Khizhnyak, I. (2018), A Swarm Method for Segmentation of Images Obtained from On-Board Optoelectronic Surveillance Systems, 2018 International Scientific-Practical Conference Problems of Infocommunications. Science and Technology (PIC S\&T). https://doi.org/10.1109/infocommst.2018.8632045. 


\section{Список літератури}

1. Chemin Y. Remote Sensing of Planet Earth. Rijeka. 2012. 250 p. https://doi.org/10.5772/2291. $30062-2$

2. Richards J. Remote Sensing Digital Image Analysis. An Introduction. Springer. 2013. https://doi.org/10.1007/978-3-642-

3. Bhadoria P., Agrawal S., Pandey R. Image Segmentation Techniques for Remote Sensing Satellite Images. IOP Conference Series: Materials Science and Engineering: 2020. P. 1-17. https://doi.org/10.1088/1757-899X/993/1/012050.

4. Kaur H. Review of remote sensing image segmentation techniques. International Journal of Advanced Research in Computer Engineering \& Technology. 2015. Vol. 4. Issue 14. P. 1667-1674.

5. Varghese N., Babu P. A Survey on remote sensing image segmentation. International Journal of Scientific Engineering and Applied Science. 2016. Vol. 2. Issue 1. P. 488-491.

6. Srinivas CH. V. V. S., Prasad M. V. R. V., Sirisha M. Remote Sensing Image Segmentation using OTSU Algorithm. International Journal of Computer Applications. 2019. Vol. 178. No. 12. P. 46-50.

7. Dhanachandra N., Manglem K., Jina Chanu Y. Image Segmentation Using K -means Clustering Algorithm and Subtractive Clustering Algorithm. Procedia Computer Science. 2015. Vol. 54. P. 764-771. https://doi.org/10.1016/j.procs.2015.06.090.

8. Gonzalez R. C., Woods R. E. Digital Image Processing. Prentice Hall. 2017. 1192 p.

9. OpenCV library. web site. URL: https://opencv.org.

10. ESTI MAP. Передовые технологии в обработке ДДЗ. веб-сайт. URL: http://www.mapinfo.ru/product/erdas.

11. ScanEx Image Processor. web site. URL: https://www.scanex.ru/software/scanmagic/.

12. Erdas Imagine - мощный пакет для обработки данных. веб-сайт. URL: https://softprom.com/ru/vendor/hexagon/product/erdas-imagine-

13. Scanex - лидер в сфере спутникового мониторинга. веб-сайт. URL: http://scanex.ru.

14. Sharma N., Aggarwal Lalit M. Automated medical image segmentation techniques. Journal of Medical Physics. 2010. Vol. 35. No.1. P. 3-14. https://doi.org/10.4103/0971-6203.58777.

15. Ruban I., Khudov H., Makoveichuk O., Khizhnyak I., Khudov V., Podlipaiev V., Shumeiko V., Atrasevych O., Nikitin A., Khudov R. Segmentation of opticalelectronic images from on-board systems of remote sensing of the Earth by the artificial bee colony method. Eastern-European Journal of Enterprise Technologies. 2019. Vol. 98. No. 2/9. P. 37-45. https://doi.org/10.15587/1729-4061.2019.161860.

16. Ruban I., Khudov H., Makoveichuk O., Chomik M., Khudov V., Khizhnyak I., Podlipaiev V., Sheviakov Y., Baranik O., Irkha A. Construction of methods for determining the contours of objects on tonal aerospace images based on the ant algorithms. Eastern-European Journal of Enterprise Technologies. 2019. Vol. 101. No. 5/9. P. 25-34. https://doi.org/10.15587/1729-4061.2019.177817.

17. Ruban I., Khudov H., Khudov V., Khizhnyak I., Makoveichuk O. Segmentation of the images obtained from onboard optoelectronic surveillance systems by the evolutionary method. Eastern-European Journal of Enterprise Technologies. 2017. Vol. 5. Issue 9 (89). P. 49-57. https://doi.org/10.15587/1729-4061.2017.109904.

18. Dorigo M., Stætzle T. Ant Colony Optimization: Overview and Recent Advances. International Series in Operations Research \& Management Science. 2018. P. 311-351. https://doi.org/10.1007/978-3-319-91086-4_10.

19. WorldView-1 Satellite Sensor. Satellite Imaging Corporation. web site. URL: http://www.satimagingcorp.com/satellitesensors/worldview-1.

20. Karaboga D., Gorkemli B., Ozturk C., Karaboga N. A comprehensive survey: artificial bee colony (ABC) algorithm and applications. Artificial Intelligence Review. 2014. Vol. 42. Issue 1. P. 21-57. https://doi.org/10.1007/s10462-012-9328-0.

21. Ruban I., Khudov V., Makoveichuk O., Khudov H., Khizhnyak I. A Swarm Method for Segmentation of Images Obtained from On-Board Optoelectronic Surveillance Systems. 2018 International Scientific-Practical Conference Problems of Infocommunications. Science and Technology (PIC S\&T). 2018. https://doi.org/10.1109/infocommst.2018.8632045.

\section{Відомості про авторів:}

\section{Худов Геннадій Володимирович} доктор технічних наук професор начальник кафедри

Харківського національного університету

Повітряних Сил ім. І. Кожедуба,

Харків, Україна

https://orcid.org/0000-0002-3311-2848

\section{Хижняк Ірина Анатоліївна}

кандидат технічних наук

викладач

Харківського національного університету

Повітряних Сил ім. І. Кожедуба,

Харків, Україна

https://orcid.org/0000-0003-3431-7631
Information about the authors:

\section{Hennadii Khudov}

Doctor of Technical Sciences Professor

Head of Department

of Ivan Kozhedub Kharkiv

National Air Force University,

Kharkiv, Ukraine

https://orcid.org/0000-0002-3311-2848

\section{Irina Khizhnyak}

Candidate of Technical Sciences

Istructor

of Ivan Kozhedub Kharkiv

National Air Force University,

Kharkiv, Ukraine

https://orcid.org/0000-0003-3431-7631 


\title{
ПОРІВНЯЛЬНА ОЦІНКА ЯКОСТІ СЕГМЕНТАЦІЇ ОПТИКО-ЕЛЕКТРОННИХ ЗОБРАЖЕНЬ МЕТОДОМ НА ОСНОВІ МУРАШИНОГО АЛГОРИТМУ ТА МЕТОДОМ ШТУЧНОЇ БДЖОЛИНОЇ КОЛОНІЇ
}

\author{
Г.В. Худов, І.А. Хижняк
}

У статті розглянуті методи ройового інтелекту, а саме, удосконалений метод на основі мурашиного алгоритму та метод штучної бджолиної колонії. Метою роботи є проведення порівняльної очінки якості сегментачії оптикоелектронних зображень методом на основі мурашиного алгоритму та методом штучної бджолиної колонії. Проведена сегментація тонових оптико-електронних зображень запропонованими методами ройового інтелекту. Наведено результати сегментації оптико-електронних зображень, які отримані з космічного апарату. Проведена візуальна оцінка якості результатів сегментачї вдосконаленими методами. Розраховані класичні помилки першого та другого роду сегментації оптико-електронних зображень для запропонованих методів ройового інтелекту та для відомих методів сегментування. Встановлено, щцо при використанні розроблених методів помилки першого та другого роду визначення об 'єктів інтересу на тонових оптико-електронних зображеннях знижені у порівнянні з відомими методами сегментування. Визначено особливості використання кожного із запропонованих методів ройового інтелекту, коло завдань, для яких краще використовувати кожен із запропонованих методів ройового інтелекту. Встановлено, щуо для вирішення задачі виділення областей на оптико-електронному зображенні необхідно використовувати метод штучноі бджолиної колонії. Для виділення контурів на оптико-електронному зображенні необхідно використовувати метод на основі мурашиного алгоритму.

Ключові слова: сегментація, оптико-електронне зображення, ройовий інтелект, мурашиний алгоритм, метод штучної бджолиної колонії, очінка якості, помилки першого та другого роду.

\section{СРАВНИТЕЛЬНАЯ ОЦЕНКА КАЧЕСТВА СЕГМЕНТАЦИИ ОПТИКО-ЭЛЕКТРОННЫХ ИЗОБРАЖЕНИЙ МЕТОДОМ НА ОСНОВЕ МУРАВЬИНОГО АЛГОРИТМА И МЕТОДОМ ИСКУССТВЕННОЙ ПЧЕЛИНОЙ колОнии}

Г.В. Худов, И.А. Хижняк

В статье рассмотрены методы роевого интеллекта, а именно, усовериенствованный метод на основе муравьиного алгоритма и метод искусственной пчелиной колонии. Целью работы является проведение сравнительной оценки качества сегментации оптико-электронных изображений методом на основе муравьиного алгоритма и методом искусственной пчелиной колонии. Проведена сегментация тоновых оптико-электронных изображений предложенными методами роевого интеллекта. Приведены результаты сегментации оптико-электронных изображений, которые получены с космического аппарата. Проведена визуальная оченка качества результатов сегментации усовершенствованными методами. Рассчитаны классические ошибки первого и второго рода сегментации оптико-электронных изображений для предложенных методов роевого интеллекта и для известных методов сегментаиии. Определены особенности использования каждого из предложенных методов роевого интеллекта, круг задач, для которых лучше использовать каждый из предложенных методов роевого интеллекта.

Ключевые слова: сегментаиия, оптико-электронное изображение, роевой интеллект, муравьиный алгоритм, метод искусственной пчелиной колонии, оченка качества, оиибки первого и второго рода. 